\title{
Demokratyzacja pozorna czy realna? Kilka uwag o ewolucji składu Senatu w debacie konstytucyjnej Sejmu Ustawodawczego
}

PAWe magiera - absolwent Wydziału Prawa i Administracji oraz Instytutu Historii Uniwersytetu Jagiellońskiego w Krakowie. Od 2017 roku doktorant na Wydziale Historii i Dziedzictwa Kulturowego Uniwersytetu Papieskiego Jana Pawła II w Krakowie. Zainteresowania naukowe: historia polityczna i ustrojowa Polski w XX wieku (zwłaszcza dzieje polskiego parlamentary$\mathrm{zmu}$ ), historia regionalna i historia sportu. 
Spory o Rzeczpospolita. Przeglad wybranych dyskusji politycznych $i$ ustrojowych w ostatnim stuleciu, red. P. Gofron, A. Matuła, A. Paderewska, Kraków 2020, S. 118-133.

toku prac konstytucyjnych nad zrębami ustroju II Rzeczpospolitej, prowadzonych w Sejmie Ustawodawczym, szczególnie kontrowersyjnym problemem stało się rozstrzygnięcie kwestii struktury przyszłego parlamentu. Sprowadzało się ono do podjęcia decyzji co do zasadności istnienia drugiej izby ustawodawczej, czyli Senatu. Zagadnienie to stało się przedmiotem obszernej i pełnej sporów politycznych debaty, która niejednokrotnie zatracała swój merytoryczny wymiar pod ciężarem emocjonalnej i demagogicznej argumentacji. Szczególnie ważnym elementem debaty o Senacie był problem określenia składu projektowanej izby wyższej. Wynikało to z faktu, iż zwolennicy jednoizbowości, atakując kolejne pomysły dotyczące sposobu wyłaniania senatorów, negowali tak naprawdę samą ideę drugiej izby. Ponadto charakter pojawiających się w tym względzie propozycji, noszących na sobie częstokroć pewien rys konserwatywny (np. obecność wirylistów), stanowił łatwy cel dla ideologicznych ataków. W związku z tym poszukiwanie akceptowalnej przez większość sejmową koncepcji składu Senatu, należało do kwestii najbardziej kontrowersyjnych i absorbujących uwagę autorów konstytucji.

Analizując problematykę składu Senatu w toku debaty konstytucyjnej Sejmu Ustawodawczego, zauważyć można stopniową ewolucję pojawiających się w tym względzie założeń. Polegała ona na odchodzeniu od skomplikowanych koncepcji izby wyższej złożonej z różnych kategorii wirylistów, na rzecz wizji demokratycznych, za- 
kładających wyłanianie senatorów w drodze wyborów powszechnych. Efektem końcowym tego procesu były postanowienia Konstytucji marcowej, które przewidywały niemal identyczny tryb wyboru obu izb ustawodawczych, oparty na tych samych pięciu przymiotnikach wyborczych, a różniący się głównie odmiennymi cenzusami wieku przy prawie wybierania i wybieralności. Ewolucja ta nastąpiła w okresie od przedstawienia Sejmowi projektu Komisji Konstytucyjnej (lipiec I920), aż do uchwalenia Konstytucji marcowej (I7 marca I92I), i wynikała w dużej mierze ze względów natury politycznej. Kolejne wizje składu Senatu, przedstawiane przez sejmową Komisję Konstytucyjną, miały być w przekonaniu ich autorów (zwolenników izby wyższej) dowodem na poszukiwanie kompromisu politycznego z „antysenacko” nastawioną częścią Konstytuanty. Inaczej widziały tę kwestię ugrupowania przeciwne Senatowi, które dostrzegały w kolejnych projektach Komisji jedynie dwulicowe dążenia do pozornej demokratyzacji „izby panów”, oznaczające w praktyce utrwalenie jej „antyludowego” i zachowawczego charakteru.

W związku z powyższym, warto zastanowić się, czy stopniowa demokratyzacja koncepcji składu Senatu, postępująca w toku prac nad konstytucją, miała realny, czy jedynie pozorowany charakter. Próba oceny tego zagadnienia przez pryzmat najważniejszych głosów w debacie sejmowej nad składem izby wyższej, będzie głównym celem niniejszego opracowania. Dlatego też punkt wyjścia dla podjętych rozważań stanowi baza źródłowa w postaci sprawozdań stenograficznych i druków Sejmu Ustawodawczego. Odwołano się również do bogatej literatury przedmiotu, dotyczącej prac nad Konstytucją marcową i debaty ustrojowej u zarania II Rzeczpospolitej.

Zawartość merytoryczna artykułu została podzielona na cztery części, które przedstawiają charakterystyczne etapy zmian w koncepcji składu Senatu, zaistniałe $\mathrm{w}$ trakcie debaty konstytucyjnej. W ich obrębie dokonano prezentacji i oceny poszczególnych wypowiedzi posłów. Zasadniczą treść artykułu poprzedzono krótkimi uwagami wstępnymi i zwieńczono podsumowaniem. 


\section{Skład Senatu w projekcie Komisji Konstytucyjnej z czerwca 1920 roku}

Przedmiotem właściwej debaty konstytucyjnej, którą uznano formalnie za II i III czytanie projektu konstytucji, był projekt opracowany przez Komisję Konstytucyjną i przedłożony w Sejmie Ustawodawczym w postaci jej sprawozdania z I2 czerwca 1920 roku ${ }^{1}$ O składzie Senatu traktował art. 36 projektu. Zgodnie z jego pierwotnym brzmieniem, Senat miał być izbą wyłanianą wedle zupełnie innych zasad niż Sejm. Izba wyższa parlamentu byłaby złożona z kilku kategorii senatorów, ale żadna z nich nie miała pochodzić z wyborów powszechnych. Czynnik polityczny, wtórny wobec reprezentacji sejmowej, miało stanowić 70 senatorów wybieranych proporcjonalnie przez izbę niższą, spoza jej składu. Ponadto w Senacie mieli się znaleźć: przedstawiciele samorządu terytorialnego (po 2 desygnowanych przez władze wojewódzkie oraz rady miejskie 6 najważniejszych miast - Warszawy, Lwowa, Krakowa, Poznania, Wilna i Łodzi), wspólnot wyznaniowych (5 delegatów episkopatu katolickiego i 3 od innych, najliczniejszych po katolicyzmie wyznań), świata nauki (przedstawiciele najwyższych uczelni i instytucji naukowych), samorządu gospodarczego (po I przedstawicielu z każdego działu Naczelnej Izby Gospodarczej), adwokatury (2 delegatów), a także wiryliści reprezentujący najwyższe sądownictwo (pierwszy prezes SN i prezes Trybunału Administracyjnego) ${ }^{2}$. W tej koncepcji Senat miał być amalgamatem różnorakich grup interesów, łącząc w sobie kilka różnych zasad wyłaniania drugiej izby - od swoistych wyborów pośrednich dokonywanych przez posłów sejmowych, aż do określonych kurii wyborczych i mandatów wirylnych.

Powyższy kształt art. 36 projektu stał się przedmiotem plenarnej debaty sejmowej na dwóch posiedzeniach - 5 i I 5 października I920 roku. W jej trakcie zwolennicy Senatu wypowiadali się dwoja-

I Druk Sejmu Ustawodawczego (dalej: SU) nr I 883, s. I-55.

2 Druk SU nr i883, s. I7-I8. 
ko. Obok głosów w pełni popierających komisyjną redakcje art. 36 (np. wypowiedzi ks. Kazimierza Lutosławskiego ze Związku Ludowo-Narodowego 3 i Antoniego Matakiewicza z Polskiego Stronnictwa Katolicko-Ludowego - podkreślano apolityczność i fachowość proponowanego przez Komisję składu) ${ }^{4}$, pojawiły się również propozycje zmian w obrębie poszczególnych grup senatorów - od niewielkich korekt, aż po w pełni autorskie rozwiązania. Alfred Halban z Klubu Pracy Konstytucyjnej proponował, aby wybór 70 senatorów przez Sejm zastąpić wyborem powszechnym i bezpośrednim dokonywanym przez obywatelis. Natomiast poseł chadecji Artemiusz Ludomir Czerniewski chciał zmniejszenia liczby senatorów wyłanianych przez izbę niższą, aby nie powielać niepotrzebnie w Senacie reprezentacji politycznej tego samego rodzaju. co w Sejmie ${ }^{6}$. Całkowicie autorską poprawkę przedstawił członek Zjednoczenia Mieszczańskiego, Adolf Świda. W jego wizji 60 senatorów miało pochodzić z wyborów powszechnych, IO z mianowania przez prezydenta, $60 \mathrm{z}$ wyborów kurialnych (proponował wprowadzenie 6 różnych kurii po Io mandatów), a skład izby miało uzupełniać 5 delegatów episkopatu katolickiego ${ }^{7}$.

Z kolei przedstawiciele ugrupowań antysenackich podkreślali niedemokratyczny, wręcz elitarny charakter proponowanych rozwiązań, kłócący się z wizją ludowej i egalitarnej Rzeczpospolitej. Wskazywano na potencjalny brak wystarczającego autorytetu senatorów, którzy nie pochodziliby z powszechnego i bezpośredniego wyboru społeczeń-

3 Przynależność klubową i partyjną uczestników sejmowej debaty konstytucyjnej ustalano na podstawie: T. Rzepecki, Sejm Rzeczypospolitej Polskiej I9I9 roku, Poznań I920; druk SU nr I 55 I.

4 Sprawozdanie Stenograficzne ze I69 posiedzenia Sejmu Ustawodawczego z dnia s października I920 r. (dalej: Spr. sten. SU nr I69 z 5 X I 920 r.), łam (dalej: ł.) 37-4I (ks. Lutosławski), 49-5 I (Matakiewicz).

5 Spr. sten. SU nr I69 z 5 X I 920 r., ł. 28-29.

6 Spr. sten. SU nr I69 z 5 X I 920 r., ł. 5 I.

7 Spr. sten. SU nr I69 z 5 X i 920 r., ł. 23. 
stwa. Krytycznego rozbioru propozycji Komisji dokonał Mieczysław Niedziałkowski (Związek Polskich Posłów Socjalistycznych), który piętnował chaotyczność i sztuczność przyjętych rozwiązań, widząc w nich jedynie zlepek dowolnie przejętych wzorców z senatów innych państw (Norwegii, Rumunii, Francji, Hiszpanii), pozbawiony klarownej myśli przewodniej. Taki Senat uznał za skazany z góry na porażkę, określił go wręcz mianem „płodu, który zmarł w łonie matki”". Jego zdaniem projektowana izba wyższa miała być ostoją żywiołów „reakcyjnych”, a samą zasadę dwuizbowości traktował jako z gruntu niedemokratyczną̧ ${ }^{9}$ Incydentalnie po stronie mówców antysenackich pojawiły się ślady konstruktywnej krytyki szczegółowych rozwiązań - np. Józefat Błyskosz z PSL uważał, iż zasadniejszym będzie wprowadzenie 3 (zamiast 2) przedstawicieli adwokatury, aby każdy reprezentował jeden pozaborczy porządek prawny. Niemniej jednak nawet takie wypowiedzi były podsumowywane w duchu zdecydowanej negacji samej idei dwuizbowości ${ }^{\mathrm{I}}$.

Patrząc na debatę, która odbyła się w październiku 1920 roku nad sprawą składu Senatu, należy zwrócić uwagę, że już wówczas w ramach wypowiedzi bloku prosenackiego pojawiały się głosy za wyborem części senatorów w drodze wyborów powszechnych. Dowodzi to, że również po stronie stronnictw zachowawczych, doceniano w pewnym stopniu ideę udzielenia Senatowi szerszej legitymacji demokratycznej, akcentując równocześnie potrzebę zapewnienia tej izbie odpowiedniej wartości fachowej (np. poprzez obecność wirylistów), aby mogła ona należycie spełnić swoje zadanie rewizji ustaw sejmowych. Nie spotkało się to jednak z szerszym zainteresowaniem ugrupowań przeciwnych dwuizbowości, które absolutyzowały swoje stanowisko, zwalczając ideę Senatu jako taką.

8 Spr. sten. SU nr I69 z 5 X I920 r., 1. 29-35.

9 W. Kowalski, Koncepcje ustrojowe izby wyższej parlamentu w II Rzeczypospolitej, Warszawa 20I4, s. I 23-I 24.

Io Spr. sten. SU nr I73 z I 5 X I920 r., ł. 35-38. 


\section{Pierwsze odesłanie art. 36 do Komisji Konstytucyjnej w listopadzie 1920 roku}

Kulminacja sporu o Senat nastąpiła 2I października I920 roku, gdy obstrukcja parlamentarna ze strony bloku antysenackiego doprowadziła do odroczenia głosowania nad art. 35-36 dotyczącymi izby wyższej ${ }^{\text {II }}$. Punktem zwrotnym, który pchnął dyskusję o Senacie na nowe tory, był wniosek posła PSK-L Antoniego Matakiewicza z 5 listopada 1920 roku, o odesłanie art. 35 i 36 z powrotem do Komisji Konstytucyjnej. Ich treść miała zostać zrewidowana w kierunku, który umożliwiałby uzyskanie kompromisu w Konstytuancie. Poseł ten rekomendował zastosowanie projektu swojego klubowego kolegi, Franciszka Maślanki, który zakładał, iż wybory do Senatu powinny być oparte na identycznych zasadach, jak te do Sejmu - miały być powszechne i demokratyczne, aby izba wyższa posiadała autorytet równy sejmowemu. Wybory pięcioprzymiotnikowe do Senatu miał jednak wyróżniać wysoki cenzus wieku przy prawie wyborczym określony na 30 lat (prawo czynne) i 40 lat (prawo bierne), duże okręgi wyborcze równe województwu oraz obejmujący kandydatów wymóg znajomości języka polskiego lub posiadania jednej kadencji doświadczenia parlamentarnego ${ }^{\mathrm{I}}$. Przyjęcie wniosku Matakiewicza przez Sejm zaowocowało pierwszym odesłaniem art. 36 do Komisji Konstytucyjnej ${ }^{\text {13 }}$.

Projekt, który powrócił z Komisji w formie jej sprawozdania z 25 listopada 1920 roku $^{14}$, zakładał iż Senat w $4 / 5$ będzie pochodził z czteroprzymiotnikowych wyborów (nie zagwarantowano jedynie przymiotnika bezpośredniości), a w I/ 5 złożą się na niego przedstawiciele wyznań ( 5 od Kościoła katolickiego, w tym I z unickiego, a także 3 od pozostałych wyznań), najwyższych zakładów i instytucji naukowych (po I) oraz

I I Zob. szerzej: Spr. sten. SU nr 176 z 2 I X I920 r., ł. I4-30.

I 2 S. Krukowski, Geneza konstytucji z I7 marca I92I r., Warszawa I977, s. 259260.

I 3 Spr. sten. SU nr I 82 z 5 XI I 920 r., ł. 4-5.

I4 Druk SU nr 2295. 
Naczelnej Izby Gospodarczej (po I z każdego działu). Usunięto więc z grona senackiego reprezentację samorządu terytorialnego (aby nie wikłać go w politykę partyjna), senatorów wybieranych przez Sejm (aby izba wyższa nie była nadmiernie od niego zależna) oraz zawodowych prawników (prezesi wyższych sądów i delegaci adwokatury). Prawo wybierania obwarowano cenzusem wieku (3o lat) oraz osiadłości (rok czasu w danym okręgu wyborczym, z wyjątkiem osiadłych kolonistów korzystających z reformy rolnej). Natomiast prawo wybieralności przysługiwało obywatelom, którzy spełnili cenzus wieku 40 lat. Nowa wersja art. 36 nie uwzględniała projektu Maślanki, ale opierała się na zgłoszonej w Komisji propozycji posła chadecji Adama Piotrowskiego, który zmodyfikował autorski projekt innego członka PSK-L, ks. Kazimierza Kotuli. Propozycja ta przeszła w Komisji większością zaledwie I głosu's .

Nowy art. 36 stał się przedmiotem obrad Sejmu na trzech kolejnych posiedzeniach, w dniach 2, 3 i 9 grudnia 1920 roku. W sprawozdaniu Komisji wygłoszonym przez jej przewodniczącego, Edwarda Dubanowicza (Narodowe Zjednoczenie Ludowe), przekonywano iż nowy projekt ma charakter kompromisowy. Miał on bowiem dążyć do zdemokratyzowania składu Senatu poprzez wybór aż 4/5 jego członków w drodze wyborów powszechnych. Wysokie cenzusy wieku miały być najłatwiejszym i najbardziej demokratycznym sposobem na uczynienie z Senatu izby rozwagi, zdolnej do mądrego korygowania ustaw. Z kolei cenzus osiadłości był nieznaczny (I rok) i doznawał istotnych wyjątków (reforma rolna). Natomiast I/5 Senatu spoza wyborów miała być wąskim gronem fachowych rzeczoznawców, pomocnym w merytorycznej pracy Senatu, ale zbyt małym, aby zdominować przyszłe działania izby i naruszyć jej demokratyczny charakter ${ }^{16}$.

I 5 S. Krukowski, Geneza konstytucji..., dz. cyt., s. 264-267; S. Krukowski, Konstytucja Rzeczypospolitej Polskiej z I92I r., w: Konstytucje Polski. Studia monograficzne z dziejów polskiego konstytucjonalizmu, t. 2, red. M. Kallas, Warszawa I990, s. 63-64.

I6 Spr. sten. SU nr I 92 z 2 XII I 920 r., ł. 57-62. 
Z interpretacją Dubanowicza gorąco polemizowali przede wszystkim socjaliści, przekonując, że zaistniała zmiana jest tylko z pozoru rozwiązaniem kompromisowym, a w istocie jest obliczona na zagwarantowanie prawicy politycznej przewagi w Senacie. Zdaniem Niedziałkowskiego, łatwość, z jaką wysunięto nową propozycję, dowodziła braku głębszej refleksji na temat kształtu Senatu w obozie jego zwolenników - mieli się oni więc kierować względami politycznymi, a nie przemyślanymi racjami prawnoustrojowymi. Poseł ten piętnował pozostawienie niektórych kategorii wirylistów, wskazując na ich nieuzasadniony i przypadkowy dobór. Duchowieństwo i samorząd gospodarczy uznał za reprezentację określonych interesów, a nie fachowych „rzeczoznawców”. Dowodem na próbę zawłaszczenia przyszłej izby wyższej przez prawicę miały być wysokie cenzusy wieku, które faworyzowały osoby o światopoglądzie konserwatywnym ${ }^{17}$.

Z innej perspektywy wypowiadał się ks. Lutosławski. Uważał poprzedni Senat za lepszy ze względów merytorycznych oraz tańszy dla państwa (brak konieczności przeprowadzania wyborów). Zaistniałą zmianę przedstawiał jako gest dobrej woli wobec lewicy, dowód na gotowość wyrzeczenia się pewnych słusznych postulatów w imię zgody na wprowadzenie Senatu. Gotowość ta była tym większa, że kwestię składu izby wyższej uważał za podlegającą negocjacjom - celem nadrzędnym dla prawicy była jakakolwiek dwuizbowość, samo istnienie Senatu jako instancji rewizyjnej wobec ustaw ${ }^{18}$. Za Senatem w pełni demokratycznym opowiedział się poseł Zjednoczenia Mieszczańskiego Aleksander de Rosset, postulując wprowadzenie podobnych wyborów do obu izb, z różnicami jedynie w obrębie cenzusów wyborczych $^{\text {19. }}$.

Patrząc na argumenty obu stron w tej fazie debaty, wydaje się, że nawet tak połowiczne rozwiązanie, jak to przyjęte przez Komisję, było

\footnotetext{
I7 Spr. sten. SU nr I93 z 3 XII I 920 r., ł. 47-52.

I 8 Spr. sten. SU nr I93 z 3 XII I 920 r., ł. 52-55.

I 9 Spr. sten. SU nr I94 z 9 XII I 920 r., ł. 44-45.
} 
krokiem w kierunku demokratyzacji Senatu. Trudno bowiem nie docenić faktu, że aż $80 \%$ izby miało pochodzić z wyborów powszechnych, choć o wyraźnie zaostrzonych cenzusach. Mimo to spora część społeczeństwa (osoby od 30 roku życia) uzyskałaby znaczny wpływ na wybór senatorów, którego we wcześniejszym projekcie nie miała. Wątpliwy był jedynie brak zagwarantowania bezpośredniości wyborów, co mogło prowadzić do rozmycia rzeczywistej woli wyborców przez pośredniość głosowania. Nawet jednak powszechne wybory pośrednie miały walor przeniesienia ich poza obszar parlamentu (oddania głosu obywatelom), w przeciwieństwie do poprzedniej propozycji, która decyzję o wyborze 70 senatorów powierzała jedynie posłom, zanadto afirmując ich rolę „przedstawicieli narodu”. Zważywszy na fakt, że podwyższenie cenzusów miało swoje racjonalne uzasadnienie (wola dywersyfikacji oblicza personalnego obu izb, chęć wyłonienia reprezentacji bardziej adekwatnej dla zadań poruczonych Senatowi) i było środkiem bardziej demokratycznym od arbitralnego doboru grup senatorów wirylistów, to trudno nie dostrzec w argumentach lewicy przysłowiowego „szukania dziury w całym”, również motywowanego troską o własne wpływy polityczne.

\section{Drugie odesłanie art. 36 do Komisji Konstytucyjnej w grudniu 1920 roku}

Ponieważ proponowany przez Komisję kształt art. 36 nie czynił zadość wnioskowi posła Maślanki, jego klub, reprezentowany w osobie Matakiewicza, zgłosił 9 grudnia 1920 roku ponowny wniosek o odesłanie art. 35-36 do Komisji. Został on przegłosowany dzień później ${ }^{20}$. Efekt prac Komisji, przedłożony Sejmowi 2I stycznia I92I roku ${ }^{21}$, stanowił syntezę propozycji Maślanki (senatorowie pochodzący z wyboru,

20 S. Krukowski, Geneza konstytucji..., dz. cyt., s. 269.

2 I Druk SU nr 2393. 
nie wprowadzono jednak cenzusów językowych i doświadczenia parlamentarnego) oraz wcześniejszych ustaleń komisyjnych (w odniesieniu do pozostałej I/s Senatu - kategorie tych senatorów pozostały bez zmian) ${ }^{22}$. Nowością było więc zagwarantowanie wyborów pięcioprzymiotnikowych (dodanie cechy bezpośredniości), a także wprowadzenie wojewódzkich okręgów wyborczych.

Zmiany te spotkały się z gwałtowną reakcją ze strony partii reprezentujących środowiska robotnicze (PPS i NPR). Reprezentujący PPS Kazimierz Czapiński uważał nową wersję art. 36 za jeszcze bardziej niedemokratyczną. Uznał, że proponowane rozwiązania są skrajnie niekorzystne dla robotników i ich reprezentacji parlamentarnej. Jego zdaniem proporcjonalny wybór części senatorów przez Sejm dawał przynajmniej partiom robotniczym pewny udział w mandatach izby wyższej, stosowny do ich siły politycznej w Sejmie. Natomiast wybory formalnie powszechne, a faktycznie ograniczone wysokim cenzusem wieku i cenzusem osiadłości godziły w interesy polityczne robotników, jako warstwy młodej i mobilnej na niepewnym rynku pracy. Ponadto skrytykował wprowadzenie wojewódzkich okręgów wyborczych, co jego zdaniem uderzało w ludność miejską (w tym robotniczą). W dużych okręgach głosy miast miały bowiem tonąć w masie głosów o wiele liczniejszej ludności wiejskiej²3. Podobne zastrzeżenia formułował również działacz Narodowej Partii Robotniczej, Bolesław Fichna ${ }^{24}$. Krytykowano fakt pozostawienia wirylistów („ogonek klerykalno-endecki”) jako realny dowód na brak dobrej woli deklarowanej przez prawicę, a także wyraz niekonsekwencji, gdyż zlikwidowano najbardziej kompetentne dla prac legislacyjnych grupy - prezesów wyższych sądów i przedstawicieli adwokatury. Podobny pogląd przedstawił też ks. Jan Kanty Madej z PSK-L, który domagając się ludowego, w pełni

22 A. Ajnenkiel, Spór o model parlamentaryzmu polskiego do roku I926, Warszawa I972, s. 232-233.

23 Spr. sten. SU nr 202 z 25 I I92 I r., ł. 5-I6.

24 Spr. sten. SU nr 202 z 25 I I 92 I r., ł. 20-23. 
demokratycznego Senatu, zapowiedział głosowanie swoich klubowych kolegów za wykreśleniem wirylistów ${ }^{25}$.

O ile można się odnieść z pewnym zrozumieniem do krytyki cenzusu osiadłości (postulat wyłączenia spod tego cenzusu robotników został jednak zrealizowany przez Komisję Konstytucyjną w toku jej finalnych prac, prowadzonych w lutym i marcu I92I roku ${ }^{26}$ ), to trudno uznać za zasadne zarzuty o niedemokratyczności wojewódzkich okręgów wyborczych. Fakt, że premiowały one w pewnym zakresie ludność wiejską, był bezpośrednią konsekwencją charakterystyki społeczno-zawodowej kraju oraz niskiego jeszcze wówczas wskaźnika urbanizacji. Nie wynikał on zatem z przesłanek czysto politycznych. Ponadto docenić należy wprowadzenie w pełni demokratycznych, już pięcioprzymiotnikowych wyborów w odniesieniu do 4/5 Senatu.

\section{Ustalenie składu Senatu w konstytucji w drodze finalnych głosowań z marca 1921 roku}

W wyniku głosowań z 28 stycznia I92I roku, w drugim czytaniu przyjęto redakcję art. $36 \mathrm{w}$ takim samym brzmieniu, w jakim powrócił on za drugim razem z Komisji Konstytucyjnej ${ }^{27}$. Ostatnie zmiany koncepcji Senatu, które zaowocowały wprowadzeniem jednolitych wyborów pięcioprzymiotnikowych na gruncie Konstytucji marcowej, miały miejsce już w trakcie III czytania. Polegały na stopniowym usuwaniu poszczególnych kategorii wirylistów. Najpierw w drodze listu, odczytanego w Sejmie przez abp. Józefa Teodorowicza 8 marca I92I roku, dostojnicy Kościoła zrzekli się zagwarantowanego miejsca w Senacie, pozostawiając tę kwestię decyzjom wyborczym obywateli.

25 Spr. sten. SU nr 202 z 25 I I92 I r., ł. I7-20.

26 Zob. druk SU nr 256I, s. 3, I 5-I7; Spr. sten. SU nr 2 I 6 z 8 III I 92 I r., ł. I4.

27 Spr. sten. SU nr 204 z 28 I I 92 I r., 1. 9-I 4. 
W związku z tym doszło też do wykreślenia przedstawicieli innych wy$z n^{28}$. Ostatnie dwie kategorie senatorów niepochodzących z wyboru zostały usunięte w drodze głosowań z I6 marca I92I roku²9. Oznaczało to, iż w składzie Senatu pozostała jedyna przegłosowana kategoria członków - senatorowie z wyborów pięcioprzymiotnikowych.

\section{Podsumowanie}

Proces ewolucji koncepcji składu Senatu, jaki dokonał się od czerwca I920 roku do marca I92I roku, zakończył się demokratyzacją tej izby. Zaistniało bowiem przejście od idei izby wyższej, opartej na zasadach mianowania, do Senatu wyłanianego w wyborach pięcioprzymiotnikowych. Przesunięcie to wynikało z dwóch okoliczności politycznych. $\mathrm{Z}$ jednej strony było to elastyczne stanowisko ugrupowań prosenackich w sprawie składu Senatu. Stronnictwa te dążyły bowiem konsekwentnie do wprowadzenia samej zasady dwuizbowości, uznając iż skład izby pozostaje kwestią drugorzędną i podlega negocjacjom. Takie podejście nie sprzyjało wypracowaniu spójnej, konkretnej wizji co do tego, jak przyszły Senat ma wyglądać. Z drugiej strony ugrupowania antysenackie zajmowały raczej sztywne stanowisko, zakładające negację istnienia jakiejkolwiek drugiej izby. Brakowało więc pozytywnego programu lewicy w sprawie składu Senatu - ograniczała się ona głównie do odrzucania kolejnych propozycji ustrojowych. Taka postawa wymuszała ustępstwa ze strony prawicy ${ }^{30}-\mathrm{w}$ tym przypadku skończyły się one przyjęciem niedoskonałej koncepcji, gdzie Sejm i Senat były wybierane wedle z grubsza tych samych zasad. Budziło to wątpliwości z punktu

28 Spr. sten. SU nr 2 I 6 z 8 III I 92 I r., ł. 2 I; Spr. sten. SU nr 2 I 9 z I 5 III I 92 I r., 1. 33 .

29 Spr. sten. SU nr 220 z I6 III I92 I r., ł. Io-I 2.

30 W. Jakubowski, K. Jajecznik, Polska debata ustrojowa w latach I9I7-I92I. Perspektywa politologiczna, Warszawa 2010, s. 71-72, 74-75. 
widzenia zasadności istnienia Senatu jako izby powielającej ten sam skład polityczny co w Sejmie. Ponadto zachodziła wtedy wyraźna, logiczna sprzeczność między szeroką legitymacją demokratyczną Senatu, a jego słabą pozycją ustrojową ą $^{3 \mathrm{~T}}$.

Czy kolejne wersje składu Senatu opracowywane przez Komisję Konstytucyjną były wyrazem szczerej intencji demokratyzacji Senatu? Wydaje się, że tak, wszak każda następna propozycja nieznacznie poszerzała wpływ obywateli na kreowanie Senatu. Ponadto należy podkreślić, iż w obozie prosenackim liczne były głosy za wyłanianiem senatorów w drodze pełnych wyborów powszechnych, choć obwarowanych cenzusami (pogląd taki wyrażał prywatnie nawet Dubanowicz ${ }^{32}$ ). Miały one wpłynąć na zróżnicowanie reprezentacji w obu izbach i wzmocnić czynnik kompetentny w Senacie, niezbędny dla izby refleksji. Kolejne, połowiczne propozycje przedstawiane przez Komisję Konstytucyjną wynikały właśnie z obawy, iż w pełni demokratyczne wybory Senatu nie zapewnią mu wystarczającego dopływu „sił fachowych”, tak potrzebnych dla tworzenia dobrej legislacji, warunkującej przecież pomyślny byt odrodzonej Rzeczpospolitej.

\section{Streszczenie}

DEMOKRATYZACJA POZORNA CZY REALNA? KILKA UWAG O EWOLUCJI SKŁADU SENATU W DEBACIE KONSTYTUCYJNEJ SEJMU USTAWODAWCZEGO

Niniejszy artykuł stanowi próbę odpowiedzi na pytanie czy proces demokratyzacji składu izby wyższej parlamentu w kolejnych projektach

3 I J. Czajowski, Dwuizbowa struktura parlamentu w państwie jednolitym, w: Parlamenty państw europejskich, red. J. Czajowski, M. Grzybowski, Kraków 2005, s. 172-178.

32 A. Kulig, Ksztattowanie formy rządów u progu niepodlegtej Polski (I9I7-I926), Warszawa 201 3, s. 299. 
sejmowej Komisji Konstytucyjnej z lat I920-192I miał charakter realny, czy był jedynie działaniem pozornym. Faktem jest bowiem odejście od początkowych koncepcji zakładających Senat wyłaniany w drodze mianowania, na rzecz idei w pełni demokratycznego wyboru drugiej izby parlamentarnej, która znalazła wyraz w Konstytucji marcowej. Zdaniem zwolenników dwuizbowości zmiany te były wyrazem dobrej woli wobec przeciwników Senatu i miały na celu pozyskanie ich zgody na wprowadzenie jakiejkolwiek izby wyższej. Z kolei zwolennicy monokameralizmu uważali te działania za jedynie pozorną demokratyzację Senatu, będącego z samej zasady instytucją zachowawczą. Próbę odpowiedzi na tytułowe pytanie podjęto w oparciu o analizę najważniejszych głosów w debacie konstytucyjnej. Korzystano przy tym ze źródeł parlamentarnych - druków i stenogramów Sejmu Ustawodawczego oraz z podstawowej literatury przedmiotu.

\section{Summary}

REAL OR OSTENSIBLE DEMOCRATIZATION? A FEW REMARKS ON THE EVOLUTION OF THE COMPOSITION OF THE SENATE IN THE CONSTITUTIONAL DEBATE OF THE LEGISLATIVE SEJM

The article is an attempt to answer the question if the process of democratization of the upper house of parliament in subsequent drafts of constitution prepared by the parliamentary Constitutional Commission (in years I920-I92I) was real or was it only an ostensible movement. In fact during the constitutional efforts initial concept of creating the Senate through nomination was changed in favor of the idea of the democratic elections to the upper house of parliament. That regulation was also finally implemented in the March Constitution of Poland. In opinion of the adherents of bicameralism those changes were the results of a compromise with the political opponents that was made to implement the Senate to the constitution. On the other hand, the adherents of monocameralism were convinced 
that every upper house of parliament is reactionary and that the all new concepts of the Senate were only an ostensible democratization. The attempt to resolve the question that was given in the title based on the analysis of the most important speeches in the constitutional debate. The paper was prepared mainly using the parliamentary sources which are the documents and stenographic records of the Legislative Sejm. Also, basic literature was an important support.

\section{Bibliografia}

\section{ŹRÓDŁA}

Druki Sejmu Ustawodawczego RP (I919-1922).

Sprawozdania Stenograficzne z posiedzeń Sejmu Ustawodawczego RP (I919-1922).

\section{OPRACOWANIA}

Ajnenkiel A., Spór o model parlamentaryzmu polskiego do roku I926, Warszawa 1972.

Czajowski J., Dwuizbowa struktura parlamentu w państwie jednolitym, w: Parlamenty państw europejskich, red. J. Czajowski, M. Grzybowski, Kraków 2005.

Jakubowski W., Jajecznik K., Polska debata ustrojowa w latach I9I7-I92I. Perspektywa politologiczna, Warszawa 2010.

Kowalski W., Koncepcje ustrojowe izby wyższej parlamentu w II Rzeczypospolitej, Warszawa 2014.

Krukowski S., Geneza konstytucji z I7 marca I92I r., Warszawa 1977.

Krukowski S., Konstytucja Rzeczypospolitej Polskiej z I92I roku, w: Konstytucje Polski. Studia monograficzne z dziejów polskiego konstytucjonalizmu, t. 2, red. M. Kallas, Warszawa 1990.

Kulig A., Ksztattowanie formy rządów u progu niepodlegtej Polski (I9I7I926), Warszawa 2013.

Rzepecki T., Sejm Rzeczypospolitej Polskiej I9I9 roku, Poznań I920. 